\title{
MULTICULTURALISMO E CURRÍCULO: UM ESTUDO SOBRE A SITUAÇÃO DO ESTUDANTE AFRICANO EM UMA ESCOLA DE FORTALEZA
}

\author{
Antônio Vinnie dos Santos Silva; Natal Lânia Roque Fernandes \\ Instituto Federal de Educação, Ciência e Tecnologia do Rio Grande do Norte (IFRN); \\ Instituto Federal de Educação, Ciência e Tecnologia do Ceará (IFCE)
}

DOI: $10.15628 /$ rbept.2019.7829

Artigo submetido em out/2018 e aceito em jun/2019

\begin{abstract}
RESUMO
O presente estudo tem por objetivo desenvolver uma reflexão acerca da situação dos estrangeiros africanos que vêm à cidade de Fortaleza-CE para estudar em escolas de cursos técnicos e profissionalizantes. Com base nos estudos sobre multiculturalismo (WERNECK, 2008; CANEN, 2007), Currículos (SILVA, 1999; GIMENO SACRISTÁN (2000) e relações étnico-raciais (COELHO, 2005) foi realizado um estudo de caso, com entrevistas semiestruturadas a um estudante guineense e a um membro da secretaria de uma escola técnica da rede privada de ensino de Fortaleza-CE. A pesquisa revelou que há, com relação ao estudante africano, distanciamento e falta de adequação curricular para acolhê-lo. Tal situação ocorre desde o primeiro dia de ida ao ambiente escolar e atinge, entre outros aspectos, a vestimenta e o idioma dos estrangeiros de origem africana: um misto de português com crioulo, que são duas línguas típicas de muitos países africanos.
\end{abstract}

Palavras-Chave: Multiculturalismo. Relações étnico-raciais. Currículo.

\section{MULTICULTURALISM AND CURRICULUM: A STUDY ON THE SITUATION OF THE AFRICAN STUDENT IN A SCHOOL IN FORTALEZA}

\begin{abstract}
The present study aims to develop an investigation into the situation of African foreigners who have arrived in the city of Fortaleza-CE to study in schools of courses and professionals. Based on the studies on multiculturalism (WERNECK, 2008; CANEN, 2007), Curriculum (SILVA, 1999; GIMENO SACRISTÁN, 2000) and ethnic-racial relations (COELHO, 2005) a case study was conducted, with semi-rolled interviews in a Guinean student and a member of secret science of the round-the-education education for Fortaleza-CE. to the school environment and affects, among other things, the clothing and language of foreigners of African origin: a mixture of Portuguese and Creole, which are two languages typical of many African countries.
\end{abstract}

Keywords: Multiculturalism. Ethnic-racial relations. Curriculum. Professional education. 


\section{INTRODUÇÃO}

Diante de crescimento econômico pouco expressivo e notícias diárias de corrupção envolvendo o mais alto escalão do nosso sistema político, a descrença da população em dias melhores é evidente. Por mais pessimistas que possamos ser, é inegável que o Brasil é um país de muitas oportunidades. Todavia, devemos reconhecer que as oportunidades oferecidas no âmbito da educação precisam evoluir bastante, principalmente no que se refere à contemplação das relações étnico-raciais nos currículos de nossas instituições de ensino. A abordagem dessa temática se faz de suma importância no contexto brasileiro, cuja formação sócio-histórica é marcada pelo multiculturalismo.

Podemos observar, de acordo com os dados seguintes, que o Brasil ocupa posição de destaque no cenário mundial quando concebido numa perspectiva de país que acolhe pessoas de diversas nacionalidades, que vêm com objetivos variados, como a busca por qualificação profissional e por melhores condições de vida. Neste sentido, as terras brasileiras acabam sendo procuradas significativamente por pessoas de outros continentes, em especial por aqueles que são falantes da língua portuguesa.

Para melhor justificar a crescente busca pelo mercado brasileiro, vamos tecer algumas considerações sob a perspectiva da nossa economia e de sua relação com o resto do mundo. O gráfico 1 deixa clara a relevância do Brasil frente aos países falantes de língua portuguesa. O país que mais se aproxima da economia brasileira é Portugal, que a partir dos anos 2000 consegue manter seu Produto Interno Bruto (PIB) na casa dos $\$ 250$ bilhões (apesar de que em 2015 teve uma queda para $\$ 198$ bilhões), ao passo que o Brasil em 2011 chegou a atingir a cifra de \$2,6146 trilhões, o que corresponde a mais de 10 vezes o PIB português para o mesmo período. Guiné-Bissau, por exemplo, país de origem do estudante entrevistado, somente conseguiu atingir a casa do primeiro $\$ 1,0$ bilhão em 2011, mantendo-se nessa faixa até os dias de hoje. Importante ressaltar ainda que a diferença da economia brasileira para as demais, conforme o gráfico 1, é tão larga que as variações de PIB, em especial dos países africanos, sequer 
são suficientes para mudar esse quadro de discrepância por um só momento, de acordo com a escala do gráfico.

Já no cenário econômico mundial, o Brasil ocupa posição de destaque. Em 2011 éramos a sexta maior potência econômica, quando superamos o Reino Unido (FALCÃO, 2012). Com as crises política e econômica, esta iniciada em 2014 e persistindo ainda em 2017, estamos na 9a posição do ranking mundial, segundo dados do Banco Mundial, mas ainda assim aparecemos como protagonistas, com perspectivas de que neste ano de 2017 o país chegue à $8^{a}$ posição, ultrapassando a Itália, permanecendo nessa posição até 2021, conforme anunciado pelo Fundo Monetário Internacional (IMF, 2016). Internamente, apesar de o mercado de eletrônicos, importante setor da economia, estar amargando quedas, a previsão para 2017 é um pouco melhor (ROCHEL, 2016).

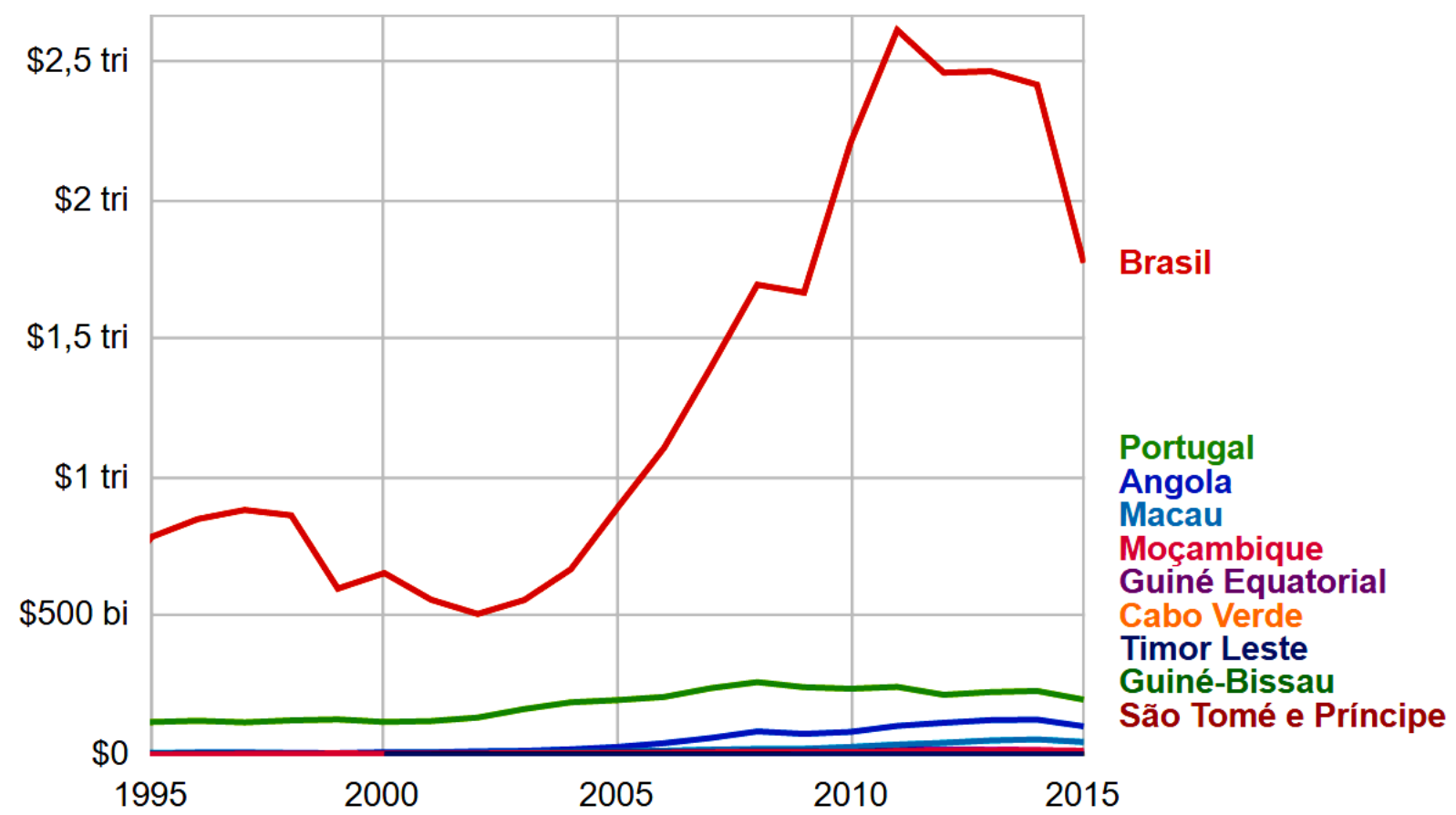

Gráfico 1: Evolução do PIB de países falantes da língua portuguesa.

Fonte: Retirado do Google Public Data Explorer com base nos dados do Banco Mundial.

Por tais motivos, o Brasil abraça a todos que chegam, oferecendo aos nossos irmãos africanos, de modo específico aqueles que falam português, oportunidades em diferentes áreas. Assim, pelos dados supracitados, o Brasil 
vem figurando como local adequado dos estrangeiros que vêm para cá em busca de melhores condições de vida.

Nesse contexto, em que é crescente o número de jovens africanos que desembarcam no Brasil (conforme veremos adiante), é necessário refletir sobre a atual capacidade das escolas em lidar com esse público, que, apesar de compartilhar da mesma língua, traz consigo sua cultura, seus costumes e seus medos. É preciso, portanto, pontuar os níveis de integração dessas pessoas com o ambiente escolar e com o currículo propriamente dito a fim de compreender em que medida esses indivíduos realmente estão sendo acolhidos e respeitados em suas particularidades.

Assim sendo, o objetivo deste artigo consiste em desenvolver uma reflexão acerca da situação dos estudantes estrangeiros africanos que vêm à cidade de Fortaleza-CE estudar em escolas de cursos técnicos e profissionalizantes. $O$ interesse pelo assunto foi suscitado a partir da minha experiência profissional como professor de cursos profissionalizantes, dos quais não raramente participam pessoas de origem africana. Esses alunos conseguem autorização no seu país, deixam familiares à espera da volta, fazem testes e ainda precisam vivenciar grandes choques de realidade, com colegas de classe muitas vezes indiferentes e uma realidade socioeconômica não muito acolhedora. Assim como os africanos, também me deparo com alunos de outras ascendências, como a europeia. Todavia, estes parecem se integrar com mais facilidade.

Em certa turma da escola local da pesquisa, havia um aluno descendente de alemão, e era marcante sua participação e interação com os demais da turma. Ele é apenas um exemplo de muitos outros estudantes não africanos com atuação marcante em sala de aula. Dos depoimentos, é possível inferir a confiança como fator determinante. O estudante africano deriva de um país com tecnologia bem aquém do restante do mundo. Chegando ao Brasil ele se depara com dispositivos, softwares e ferramentas de trabalho inovadoras, o que muitas vezes o intimida, deixando de se posicionar e discutir a respeito do assunto.

Diante dessa realidade, sentimos a necessidade de compreender como alguns estudantes africanos se sentem na escola? Como se sentem 
numa sociedade como Fortaleza? Por que escolheram Fortaleza? Quais as dificuldades? Quais as expectativas? Para alcançar nosso objetivo, desenvolvemos um estudo de caso cujo referencial teórico tem como base os estudos sobre multiculturalismo (WERNECK, 2008; CANEN, 2007), Currículos (SILVA, 1999; GIMENO SACRISTÁN, 2000) e relações étnicoraciais (COELHO, 2005). O multiculturalismo, em sua amplitude, alcança diversos significados entre os estudiosos. Ele pode se referir à presença e relação de várias culturas numa mesma sociedade (WERNECK, 2008). Além disso, Canen (2007) defende que a denominação mais adequada seria interculturalismo, visto que o prefixo inter possui significado de entrelaçamento de culturas, e não uma simples composição.

Numa visão agregadora, Gonçalves e Silva (2003) defendem que ao multiculturalismo são atribuídos atores, os quais definem a as regras de um jogo das diferenças, que por sua vez é marcado por discriminação e preconceitos sociais. Dessa forma, as regras do jogo apenas são compreendidas se contextualizadas em aspectos sócio-históricos.

$\mathrm{Na}$ dinâmica estabelecida pelas relações multiculturais figura 0 conceito de currículo, que muitas vezes está atrelado ao processo de construção social, assumindo papel transversal na significação e na identidade do sujeito dentro do campo de luta (SILVA, 1999). Gimeno Sacristán (2000) salienta que o termo currículo deriva da palavra latina currere, referindo-se à carreira, um percurso a ser atingido. Enquanto a escolaridade pode ser entendida como um caminho a ser trilhado, o currículo é aquele que confere forma ao decurso, fazendo o indivíduo alcançar o desenvolvimento. Portanto, considera-se que o currículo tem papel importante para o desenvolvimento do sentimento de pertencimento do sujeito estrangeiro à escola, à sociedade.

Segundo PETIT et al. (2015), o pertencimento étnico-racial é o que explica o porquê de muitos afrodescendentes adotarem comportamento negativo. Também questões emocionais levam ao silenciamento e à autodesvalorização. 
raciais que classificam aqueles que pertencem e os que não pertencem a determinados grupos sociais. Conforme aponta Dagmar Meyer (2002), um olhar mais atento revela que essas fronteiras, em sua versão dominante, foram determinadas tomando como referência a Europa branca, cristã e masculina do lluminismo [...] Portanto, entendemos que os sentidos do pertencimento e exclusão são produzidos por discursos implicados em relações de poder que fazem circular na linguagem representações étnicoraciais que nos interpelam e nos constituem como sujeitos. (ZUBARAN; SILVA, 2002, p. 131-132 apud PETIT et al., 2015, p. 129).

Além dos autores supracitados, outros autores estudiosos da temática foram tomados como referencial. Dentre eles, destacam-se: Bourdieu (2000), Coelho $(2005,2013)$ e Freire (1974). Além da literatura básica também foram selecionados alguns instrumentos legais para respaldo das informações, tais como a Lei no 10.639/2003; bem como algumas reportagens de jornais com a finalidade de relacionar com dados atuais.

O estudo foi organizado da seguinte forma: o primeiro capítulo, intitulado: Relações étnico-raciais e currículo: educação multicultural? No qual são apresentados discussões que envolvem a relação currículo, multiculturalismo e relações étnico-raciais. O segundo: Procedimentos metodológicos, no qual são expostos os caminhos percorridos para realizar o estudo. O Terceiro capítulo: No semblante, um misto de dúvidas e esperanças. O qual retrata a análise realizada das entrevistas realizadas e por fim, a conclusão.

\section{RELAÇÕES ÉTNICO-RACIAIS E CURRÍCULO: EDUCAÇÃO MULTICULTURAL?}

Embora tardiamente, o debate sobre relações étnico-raciais nos currículos brasileiros vem ganhando notoriedade. A preocupação com 0 assunto passou a ser foco de diversos autores (GRANT, 2000; MCLAREN, 2000; CANEN, 1999, 2001; CANEN \& GRANT, 1999; CANEN \& MOREIRA, 2001), os quais enfatizam que condutas discriminatórias permanecem e se renovam sutilmente (COELHO, 2005). Se pensarmos em nossa formação social e histórica, perceberemos que tais condutas se consolidaram com a imposição de uma cultura dominante: a eurocêntrica, marcas ainda da colonização (BHABHA, 1998). 
Trata-se de uma cultura difundida mundialmente, que desprivilegia a participação dos negros, quando convém, na constituição da sociedade brasileira, ao passo que o branco assume uma posição de poder em decisões importantes, confiadas aos mais altos escalões empresariais. Conforme Coelho (2005), o que persiste é uma "[...] segregação simbólica, constante, mas nunca absoluta, exercida por meio de práticas cotidianas - veladas ou não - que reduzem o negro à condição de agente inexistente do processo educacional" (p. 27).

Mesmo diante das adversidades encontradas, o negro brasileiro vem ocupando outros espaços em busca de construir novos projetos de vida. Temos como exemplo o fato de muitos africanos estarem acessando os diversos níveis de educação, muito embora tal acesso seja mais recorrente em localidades que não fazem parte de seu país de origem. As oportunidades ainda incipientes transformam-se simultaneamente em desafios: sair do lugar onde nasceu, distanciar-se da família e dos amigos, renunciar a costumes já entranhados no cotidiano.

Canclini (2000 apud COELHO, 2005) ressalta que, num contexto de mescla de culturas, não podemos desconsiderar o fato de que existe a interferência de diversos atores. Bourdieu (2000) ratifica essa ideia ao defender que as novas experiências vivenciadas pelos indivíduos em determinada realidade fazem com que estes também se tornem construtores de práticas sociais.

Uma realidade brasileira, e mais especificamente cearense, que hoje podemos identificar como uma prática social movida por grande contingente de negros é a criação da Universidade da Integração Internacional da Lusofonia Afro-Brasileira (Unilab). A Unilab nasceu da cooperação de diversos países, principalmente aqueles membros da Comunidade dos Países de Língua Portuguesa (CPLP). A instituição, que possui campi no Ceará e na Bahia, foi criada pela Lei oํ 12.289/2010 e instalada em 2011.

A Unilab tem como missão ${ }^{1}$ formar recursos humanos para contribuir com a integração entre o Brasil e os demais países membros da Comunidade dos Países de Língua Portuguesa (CPLP) - especialmente os países

\footnotetext{
${ }^{1}$ Disponível em: <http://www.unilab.edu.br/institucional-2/>. Acesso em: 23 jan. 2017.
} 
africanos - e promover o desenvolvimento regional e o intercâmbio cultural, científico e educacional.

Nessa perspectiva, a universidade apresenta em seus cursos disciplinas que possibilitam a integração do seu corpo discente, além de estudos minuciosos sobre dados históricos da cultura africana no Brasil. Essa metodologia, presente no currículo do curso de Licenciatura em Física, por exemplo, contribui para o estreitamento da relação de africanos com brasileiros (as vagas nos cursos são de 50 \% para estudantes de origem africana).

Um aspecto referente a relações étnico-raciais que merece ser ressaltado consiste na promulgação da Lei no 10.639/2003, que altera a Lei de Diretrizes e Bases da Educação e inclui no currículo oficial da Rede de Ensino a obrigatoriedade da temática "História e Cultura Afro-Brasileira". Para reforçar o avanço obtido em termos legais, vale transcrever o que salienta a LDB em seu artigo 26-A:

$\S 1^{\circ} \mathrm{O}$ conteúdo programático a que se refere este artigo incluirá diversos aspectos da história e da cultura que caracterizam a formação da população brasileira, a partir desses dois grupos étnicos, tais como o estudo da história da África e dos africanos, a luta dos negros e dos povos indígenas no Brasil, a cultura negra e indígena brasileira e o negro e o índio na formação da sociedade nacional, resgatando as suas contribuições nas áreas social, econômica e política, pertinentes à história do Brasil.

$\S 2^{\circ}$ Os conteúdos referentes à história e cultura afro-brasileira e dos povos indígenas brasileiros serão ministrados no âmbito de todo o currículo escolar, em especial nas áreas de educação artística e de literatura e histórias brasileiras.

Com isso, fica evidente a importância de os cursos apresentarem um currículo que atenda ao que consta nos parágrafos 1 e 2 do artigo 26-A da LDB. Todavia muitas escolas, em especial aquelas que oferecem cursos técnicos profissionalizantes, adotam uma pedagogia tecnicista, isto é, suprimem valores que o aluno possui, negando a necessidade de uma abordagem social e resumindo a formação profissional apenas às demandas do mercado de trabalho brasileiro. Para Coelho (2005), trata-se de um procedimento pedagógico que visa formar agentes produtivos aptos a atenderem às funções do capital industrial. 
A Resolução Nº6 do Conselho Nacional de Educação, da Câmara de Educação Básica, de 20 de setembro de 2012 (CNE/CEB № 6/2012), define as Diretrizes Curriculares Nacionais para a Educação Profissional Técnica de Nível Médio, isto é, estabelece os princípios e critérios que devem ser observados pelas instituições de ensino públicas e privadas que atuam no segmento da educação profissional de nível médio.

O artigo 40 da CNE/CEB N 6/2012 trata da formação de professores, que deve ser em nível de graduação, na modalidade de licenciatura. Os incisos I e II do $\S 2^{\circ}$ deste artigo prevê, para os casos de docentes não licenciados, formação em nível de pós-graduação lato sensu, de caráter pedagógico, ou ainda reconhecimento de prática docente àqueles profissionais que lecionam a mais de 10 anos na educação profissional. $O$ inciso III admite ainda a possibilidade de uma segunda licenciatura, mesmo que diversa da formação na qual leciona.

Apesar da CNE/CEB N 6/2012 prever até 2020 para o cumprimento da formação mínima docente, muitos professores não estão preparados para trabalhar com práticas pedagógicas que contemplem o multiculturalismo e por isso fecham os olhos para as pessoas que atravessam o oceano, adotando uma pedagogia tradicional, a qual Paulo Freire (1974), em seu livro Pedagogia do Oprimido, caracterizava como uma concepção do tipo bancária: educação dada como um depósito, sendo o estudante responsável por guardá-la e arquivá-la. Essa metodologia obsoleta massacra o estudante, fazendo-o não identificar o vínculo entre o saber praticado nessas escolas e o mercado de trabalho do seu país de origem.

Segundo Coelho e Coelho (2013),

[...] o alcance do escopo das leis exige mais que o conhecimento historiográfico; ele demanda, também, o domínio sobre competências e habilidades docentes que permitam a crítica à tradição e a desconstruções de preconceitos relacionados ao papel dos agentes na conformação da nacionalidade e da nação [...] requer de professores, técnicos e gestores que a educação ofertada satisfaça aos objetivos da lei [...] (p. 72).

Coelho (2015) salienta que, quando não há o desenvolvimento de habilidades específicas por parte dos docentes para lidar com o público 
negro, a presença dessas pessoas fica obscurecida e toda sua bagagem cultural deixa de ser valorizada, resultado de uma estrutura curricular eurocêntrica.

Além disso, o inciso IV do artigo 14 da CNE/CEB N 6/2012 orienta para que os currículos dos cursos de formação técnica privilegie domínio intelectual das tecnologias que norteiam a área de formação. Os demais incisos seguem a mesma orientação, passando por uso de instrumentos adequados, empreendedorismo e demais parâmetros que permeiam estritamente o exercício da profissão.

Com isso, muitos continuam matriculados para, simplesmente, não perderem o visto junto à Polícia Federal, estando, pois, apenas de corpo presente. Sabem e sentem que são tratados por alguns colegas com indiferença, conforme pontuamos adiante. O resultado desse conjunto de fatores é, às vezes, o desinteresse pelo estudo.

\section{PROCEDIMENTOS METODOLÓGICOS}

A pesquisa de cunho qualitativo, tipo estudo de caso, foi realizada numa escola técnica profissionalizante. Verificamos, pelo menos na seara da escola técnica em que foi realizada a pesquisa, que entre os estudantes africanos os guineenses estavam em maior quantidade, por isso selecionamos esses alunos para a pesquisa. A ideia inicial era abordar outros estudantes, porém, por fatores aleatórios ao pesquisador, decidimos analisar um único caso.

O estudante em questão é matriculado no turno matutino, o que permitiu maior proximidade, visto que pela manhã as turmas são menos numerosas. Os cursos regulares da escola ocorrem nos períodos da manhã e da noite. Dessa forma, era no intervalo da manhã para tarde que ocorriam os diálogos. 
Assim, realizamos um estudo de caso, por meio de entrevista semiestruturada a um aluno de origem africana ${ }^{2}$, a fim de verificar sua relação com uma escola de cursos técnicos e profissionalizantes da cidade de Fortaleza, bem como a integração a esse estabelecimento de ensino.

A instituição de ensino particular é de grande porte, com mais de duas décadas de atuação, e conta com 15 unidades, sem considerar os anexos, que estão distribuídas por 7 estados, todos na região nordeste. A escola atualmente dispõe de 54 cursos de diferentes formações, entre técnicos e profissionalizantes, além de 3 cursos de nível superior.

O estudante, que doravante será chamado de Tinavouta - uma adaptação da expressão "ti na vólta", que em crioulo guineense significa "até ao teu regresso" - não permitiu gravação de áudio, nem tão pouco concordou em assinar o questionário feito, porque tem receio de uma possível publicidade do artigo em questão. As perguntas foram feitas em dias distintos dos meses de dezembro de 2016 e janeiro de 2017, de acordo com a disponibilidade do aluno.

Além do estudante, foi selecionado um membro da secretaria da escola para pontuar sua ótica a respeito da crescente demanda oriunda do outro lado do oceano. Essa última entrevista, também semiestruturada, por conta da dificuldade da entrevistada em encontrar tempo disponível, foi feita nos dias 26 e 27 de janeiro deste ano de 2017. Para preservar a identidade da secretária, no capítulo da análise ela será identificada pelo nome fictício de Magnólia.

No que concerne ao currículo em si, analisamos, como exemplo, a matriz curricular do curso de Técnico em Mecatrônica, fazendo um paralelo com a necessidade particular dos estudantes estrangeiros.

\section{NO SEMBLANTE, UM MISTO DE DÚVIDAS E ESPERANÇAS}

\footnotetext{
${ }^{2}$ Houve a tentativa de entrevistar mais de um estudante africano, mas não obtivemos consentimento, talvez por receio, visto que muitos, depois de um tempo, acabam permanecendo no Brasil de forma irregular. 
Multiculturalismo e currículo, na sua constituição, levam em consideração a história, a cultura e os costumes. Dessa forma, vou me apropriar do que diz o mestre malinês da tradição oral Hampâté Bâ:

Na África tradicional, o indivíduo é inseparável de sua linhagem, que continua a viver através dele e da qual ele é apenas um prolongamento. [...] Assim, seria impensável para o velho africano que sou, nascido na aurora deste século na aldeia de Bandiagara, no Mali, iniciar o relato de minha vida pessoal sem evocar primeiro, ainda que apenas para situá-las, minhas duas linhagens, a paterna e a materna. (BÂ, 2003, p. 23, apud PETIT, 2015, p. 31).

Hampâté Bâ, em seu livro autobiográfico - Amkoullel, O Menino Fula (2003) -, revela a dupla herança que recebeu de pai e mãe. Nesse contexto, não se pode deixar de compreender o indivíduo enquanto homem formado por cultura, costume, etc.

Nosso entrevistado não é diferente. A entrevista com ele transcorreu com naturalidade, de modo que tivéssemos um ambiente mais propício a respostas sinceras, sempre dentro do tema proposto. Notamos, durante suas falas, um semblante marcante, com diversas expressões, da esperança de vinda a Fortaleza à incerteza do futuro na capital cearense. Inicialmente, perguntei sobre sua família: seu pai, um falecido oficial, deixou de herança as possibilidades de benefícios oferecidos pelo governo da República da GuinéBissau, deixando claro que militares têm privilégios em relação ao restante da população ${ }^{3}$. Informou ainda que sua mãe ficara sozinha, desesperada com sua viagem ao Brasil, pois, além do marido, ela havia perdido o outro filho em um acidente de carro. Para diminuir a saudade, os dois se falam todos os dias. Tinavouta está há cerca de três meses em Fortaleza, morando no bairro de Messejana.

\subsection{DA REPÚBLICA DA GUINÉ-BISSAU PARA FORTALEZA}

O Brasil se torna um país procurado pela proximidade com o idioma: em Guiné-Bissau, apesar de o crioulo ser uma língua muito falada, o

\footnotetext{
${ }^{3}$ Segundo Tinavouta, militares possuem privilégios em serviços básicos. Como exemplo, falou de seu pai, que, quando muito doente, conseguiu transferência para tratamento em Portugal. 
português prevalece, sendo o idioma oficial do país. Além disso, com leis mais flexíveis de imigração, não somente Brasil, mas a América Latina também tornou-se um destino cada vez mais procurado por estudantes e refugiados africanos (BARROSO, 2009; GONÇALVES, 2016).

Quando perguntei "Por quê Fortaleza?", nosso estudante de terras longínquas foi rápido em dizer que vale mais a pena, pois, embora a violência seja mais evidente, o custo de vida menor acaba por tornar a cidade mais atrativa. Além disso, possui um tio que mora na capital cearense há muitos anos - inclusive foi ele quem deu início no seu processo de matrícula na escola de Fortaleza. Sua mãe, segundo ele, sofre muito pelo medo da violência tão marcante nas terras alencarinas ${ }^{4}$.

Sobre as expectativas, disse que atualmente não são as melhores, pois, na verdade, gostaria de ter feito um curso de enfermagem e que o atual curso de técnico em Mecatrônica não tem mercado em seu país ${ }^{5}$. Disse ainda que seu tio apenas o matriculou nesse curso porque era o de maior duração, o que lhe garantiria maior permanência no Brasil. A Polícia Federal não aceita mudança para outra instituição e a sua escola atual não oferece o curso que ele prefere.

Cabe pontuar, aqui, que muitas empresas têm conhecimento dessa situação de vulnerabilidade a que nossos irmãos africanos estão sujeitos, aproveitando-se disso para oferecerem subempregos, com salários e condições muito abaixo do aceitável. $A$ isso é dado o nome de racismo institucional, em que, segundo pesquisa da ONU (2013), coloca o Brasil como desagradável exemplo de prática racista na dinâmica econômica nacional.

\footnotetext{
${ }^{4}$ Alencarino é alusão ao grande escritor cearense, nascido em Fortaleza, José de Alencar.

${ }^{5}$ Segundo dados da CIA e do Banco Mundial, Guiné-Bissau está entre os cinco países mais pobres do mundo, tendo sua economia baseada na pesca e na agricultura. Conflitos intermitentes entre tropas do governo e uma junta militar destroem constantemente a infraestrutura do país. Em 2004, o Banco Mundial, o FMI (Fundo Monetário Internacional) e o PNUD (Programa das Nações Unidas para o Desenvolvimento) interviram com o suporte orçamental de emergência de 107 milhões de dólares, o que representa mais de $80 \%$ do orçamento nacional total. Ainda de acordo com o Banco Mundial, em 2010 a desigualdade é tamanha, que chega a penalizar $69,3 \%$ da população, parcela que vive abaixo da linha da pobreza. O Golpe de Estado ocorrido em março de 2012 agravou ainda mais o quadro econômico, que vive em constante instabilidade política. $O$ resultado de tal conjuntura se reflete na dependência de ajuda externa. A Guiné-Bissau encontra-se em 178이 lugar no Índice de Desenvolvimento Humano do PNUD de 2016, com expectativa de vida de apenas 55,5 anos.
} 
O Grupo de Trabalho das Nações Unidas sobre Afrodescendentes divulgou relatório (ONU BRASIL, 2013), em que as pesquisadoras Mireille Fanon-Mendes-France e Maya Sahli salientam que a participação dos afrodescendentes em nossa economia é de apenas $20 \%$ do PIB, apesar de representarem mais da metade da população brasileira. Além disso, a taxa de desemprego é maior entre os "afro-brasileiros" do que entre os descendentes de europeus: sendo $50 \%$ maior para aqueles. Relatam ainda que a média salarial entre os afrodescendentes é de US\$466, o que corresponde a quase metade dos US\$ 860 dos descendentes de europeus. As pesquisadoras afirmaram que "os afro-brasileiros não serão integralmente considerados cidadãos plenos sem uma justa distribuição do poder econômico, político e cultural" (VIEIRA, 2013).

Em 2016, a secretaria da Juventude do Governo do Estado do Paraná fez um experimento para constatar racismo institucional ${ }^{6}$. O vídeo foi publicado em alusão ao Dia da Consciência Negra e teve grande repercussão (GARCIA, 2016). Nas cenas, a dois grupos, de forma separada, são apresentadas fotografias de pessoas brancas (grupo 1) e pessoas negras (grupo 2) em situações idênticas. Para o grupo 1, em cada as fotos exibiam, dentre outros, executivos, design de moda e donas de casa e um "homem atrasado". Já para o grupo 2, o "executivo" (agora negro) passava a ser um "segurança de shopping" ou "motorista particular"; a design de moda passou a diarista e o "branco atrasado"tornou-se um negro "ladrão" que estava "fugindo". O vídeo estarrecedor finaliza com dados (baseados em pesquisas do IBGE, DIEESE e jornal Folha de São Paulo), os quais extraímos e destacamos abaixo (GOVERNO DO PARANÁ, 2016):

- Para $82,6 \%$ dos negros a cor da pele influencia na vida profissional.

- A maioria dos desempregados, $60,6 \%$, é de negros.

- Afrodescendente tem salário $36 \%$ menor que o do branco.

- Dos mais ricos, apenas $17 \%$ são negros.

- Os negros ocupam apenas $18 \%$ dos cargos de liderança (MANEL; AMÂNCIO, 2015).

- Apenas $11 \%$ chegam a cursar o nível superior de ensino.

\footnotetext{
${ }^{6}$ Para mais detalhes o leitor poderá consultar: http://www.contraracismo.pr.gov.br/. Acesso em: 10 jul. 2017.
} 
- $70,8 \%$ acreditam que a cor da pele influencia na carreira acadêmica.

Para Tinavouta, o que mais faz lembrar sua terra natal é a variedade de frutas que existe nos supermercados, mas se diz chateado porque, em comparação com o seu país, são muito mais caras. Disse também que é marcante a alegria e as brincadeiras dos seus colegas, no que muito se assemelham ao povo guineense. Neste ponto, parecemos nos remeter às africanidades brasileiras, que emanam justamente das nossas relações humanas.

Cabe, assim, ressaltar, conforme Munanga (1984, p. 5 apud PETIT et al., 2015, p. 137) explicita:

\begin{abstract}
Ela [a africanidade] é um conjunto dos traços culturais comuns às centenas de sociedades da África subsaariana. [...] O conteúdo da africanidade é o resultado desse duplo movimento de adaptação e de difusão. [...] em toda a África Negra a infância é sempre acompanhada dos ritos de iniciação: a criança tem sempre um contato prolongado com a mãe e tem uma dependência de linhagem muito grande, o que é fundamental. Sua referência identitária não é a nacionalidade, não é a classe social, mas, sim, seu grupo de parentesco.
\end{abstract}

As palavras de Munanga retratam bem o movimento natural que ocorre entre África e Brasil, em que os imigrantes sempre buscam se aglomerar em bairros próximos. No caso de Tinavouta, como bem destacou, seu tio foi um grande provedor, pois articulou sua matrícula na escola de Fortaleza e toda logística de estadia e transporte.

Continuando com a entrevista, Tinavouta comentou que percebeu certa inércia da população em relação aos casos de violência da cidade. Para ele, não há necessidade de se esperar por uma decisão judicial, pois a polícia já poderia "punir", contando com especial ajuda da população. Falou, ainda, que o povo em Guiné-Bissau não tolera criminosos reincidentes.

Sobre a questão social que descrevi a partir da percepção de Tinavouta, cabe pontuar que em alguns países africanos, como é o caso da nação guineense, numa mesma rua moram pessoas de classes sociais distintas, por exemplo. Então, segundo o próprio Tinavouta, moradores que detêm maiores posses resguardam os demais. 
Houve uma tentativa de discutir com Tinavouta os diversos ambientes da escola, como coordenação e secretaria. O entrevistado limitou-se a dizer que sente muita dificuldade em compreender como a instituição funciona, especialmente no que diz respeito a questões mais burocráticas, e tem a percepção de que muitas vezes é ouvido, mas não entendido.

Por fim, quando discutimos sobre seu desempenho estudantil e sua relação com a escola, Tinavouta afirmou que em alguns momentos não se sente parte da turma. Os alunos até procuram integrá-lo, mas sente que determinados professores não se preocupam especificamente com ele, principalmente no uso da língua.

Tinavouta fala português, mas o sotaque diferente cria obstáculos. Percebe também que palavras e jargões típicos do Brasil, ou talvez somente do povo cearense, às vezes atrapalha a compreensão. Contou que fez amizade com uma aluna que sempre explica alguns termos usados pelo professor. Apesar disso, se limita a comunicar-se apenas com essa colega de classe, pois não se sente à vontade para dar início a uma discussão salutar. Percebemos assim a dificuldade que alguns docentes possuem em criar um canal de comunicação efetivo, alimentando no aluno um silêncio contraproducente, afinal, como diz Freire (1987, p. 44), "não é no silêncio que os homens se fazem, mas na palavra, no trabalho, na ação-reflexão".

\begin{tabular}{c|c|c|c}
\hline Parâmetros Educacionais & $\begin{array}{c}\text { Guiné- } \\
\text { Bissau }\end{array}$ & Brasil & Noruega \\
\hline Anos de escolaridade esperados & 9.2 & 15,2 & 17,7 \\
\hline $\begin{array}{c}\text { Taxa de alfabetização de adultos (\% de 15 } \\
\text { anos ou mais) }\end{array}$ & 59,9 & 92,6 & 100 \\
\hline $\begin{array}{c}\text { Despesas governamentais em educação } \\
\text { (\% do PIB) }\end{array}$ & 2,4 & 5,9 & 7,4 \\
\hline $\begin{array}{c}\text { Taxa bruta de matrícula: pré-primário (\% } \\
\text { de crianças em idade pré-escolar) }\end{array}$ & 6 & 86 & 98 \\
\hline \begin{tabular}{c} 
Percentual da população em idade escolar \\
\hline
\end{tabular} & 114 & 110 & 100
\end{tabular}




\begin{tabular}{|c|c|c|c|}
\hline $\begin{array}{l}\text { Percentual da população em idade escolar } \\
\text { de nível médio }\end{array}$ & Indisponível & 102 & 113 \\
\hline $\begin{array}{c}\text { Percentual da população cursando nível } \\
\text { superior }\end{array}$ & Indisponível & 46 & 77 \\
\hline Tempo médio de escolaridade ${ }^{* * *}$ & 2,9 & 7,8 & 12,7 \\
\hline $\begin{array}{l}\text { População com pelo menos nível médio } \\
\text { de ensino (\% com } 25 \text { anos ou mais) }\end{array}$ & Indisponível & 57,5 & 95,3 \\
\hline Taxa de abandono escolar primário (\%) & Indisponível & $\begin{array}{l}\text { Indisponív } \\
\quad \text { el }\end{array}$ & 0,4 \\
\hline $\begin{array}{l}\text { Professores da escola primária com } \\
\text { capacitação pedagógica (\%) }\end{array}$ & 39 & $\begin{array}{l}\text { Indisponív } \\
\quad \text { el }\end{array}$ & $\begin{array}{l}\text { Indisponí } \\
\text { vel }\end{array}$ \\
\hline Número de alunos por professor & 52 & 21 & 9 \\
\hline
\end{tabular}

Tabela 1: Parâmetros educacionais de Guiné-Bissau, Brasil e Noruega.

Fonte: Dados disponibilizados no sítio do Programa das Nações Unidas para o Desenvolvimento (PNUD) e se referem aos anos de 2015 e/ou 2016, o que estava disponível. Notas:

*A Noruega foi escolhida para fator de comparação por ter atualmente (2016) o maior IDH mundial.

Os dados podem ser acessados através do endereço eletrônico: http://hdr.undp.org/en/countries/profiles.

Número médio de anos de educação recebidos por pessoas de 25 anos ou mais, convertidos a partir dos níveis de escolaridade usando durações oficiais de cada nível de ensino.

A dificuldade de aprendizagem de Tinavouta pode ser explicada também pelo sistema educacional ruim de seu país, conforme podemos observar na tabela 1. As lacunas deixadas pelo ensino guineense reverberam no comportamento do aluno, que é obrigado a acompanhar um ritmo mais intenso de estudo.

De acordo com a tabela 1, que utiliza os dados do Programa das Nações Unidas para o Desenvolvimento (PNUD) ${ }^{7}$, a discrepância entre os países traduz-se também pela destinação de percentual do PIB para a

\footnotetext{
7 Atualmente, o PNUD é uma das principais agências da ONU envolvidas no desenvolvimento da Agenda de Desenvolvimento pós-2015. O PNUD é totalmente financiado por contribuições voluntárias dos 177 países membros, que trabalham com os governos para o desenvolvimento local, atuando internacionalmente para ajudar os países a alcançar os Objetivos de Desenvolvimento do Milênio (ODMs).
} 
educação, que na Noruega chega a 7,4\%, enquanto Brasil e Guiné-Bissau destinam apenas 5,9\% e 2,4\%, respectivamente. Outro dado que chama bastante a atenção é o número de alunos por professor: Guiné-Bissau possui um número quase seis vezes maior em relação que a Noruega e cerca de duas vezes e meia maior que o Brasil.

Por fim, outra informação que destacamos é a taxa de alfabetização de adultos a partir de 15 anos. Enquanto a Noruega possui a surpreendente taxa de $100 \%$, Guiné-Bissau pouco passou da metade da população para a faixa etária considerada. O abismo das estatísticas entre os países, associado à insensibilidade do docente em não aproximar-se do aluno estrangeiro (africano), associa a este um papel coadjuvante no processo de ensino e aprendizagem, fazendo-o acreditar, por diversas vezes, que possui função secundária na libertação que o conhecimento pode dar.

\begin{abstract}
Mas, se dizer a palavra verdadeira, que é trabalho, que é práxis, é transformar o mundo, dizer a palavra não é privilégio de alguns homens, mas direito de todos os homens. Precisamente por isto, ninguém pode dizer a palavra verdadeira sozinho, ou dizê-la para os outros, num ato de prescrição, com o qual rouba a palavra aos demais. (FREIRE, 1987, p. 44).
\end{abstract}

É bem verdade que nosso país, de dimensões continentais, é detentor de uma infinidade de expressões e sotaques. Essa diversidade de falas fica muito clara para Tinavouta. Dessa forma, é imprescindível o desenvolvimento de uma mentalidade voltada para acolher, também através da linguagem, essas pessoas que vêm de tão longe, de modo que a língua seja um canal para o estabelecimento de laços de afinidade, não um entrave.

\title{
4.2A PRESENÇA DE AFRICANOS NA ESCOLA: O QUE DIZ A SECRETARIA DA ESCOLA
}

Durante a entrevista, a secretária da escola afirmou que é notável a presença crescente de africanos na escola com cerca de 80 estudantes 
matriculados durante o ano de $2016^{8}$. Muitos deles vêm em busca de uma melhor qualidade de vida, matriculando-se em cursos diversos para "terem tempo para isso" - conseguir uma melhor qualidade de vida. Segundo a secretária, o curso de maior demanda é o de Técnico em Mecatrônica, uma vez que é o curso de maior duração da escola.

Além disso, Magnólia informou que em 2016, dos 80 estudantes africanos matriculados, apenas 5 frequentavam regularmente as aulas; no mesmo ano, dos concludentes, somente 1 era africano. A secretária nota, em conversas com alunos na secretaria, que muitos fazem matrícula com 0 objetivo de obter a declaração para regularização junto à Polícia Federal e à embaixada de seu país aqui no Brasil e procuram subempregos, na maioria das vezes.

Em relação à regularização dos sujeitos africanos, vale ressaltar que segundo informações da Unidade de Imigração da Polícia Federal no Ceará, no controle que faz do número de estrangeiros que passam pelo Aeroporto Internacional Pinto Martins (Fortaleza), dos atendimentos no período de janeiro de 2010 a março de 2017, quase $81 \%$ desses atendimentos eram estrangeiros de origem africana. Esse percentual corresponde a estrangeiros na condição de temporários, que geralmente são compostos por estudantes.

O gráfico 2, a seguir, detalha as informações prestadas pela Unidade de Imigração da Polícia Federal no Ceará. Destaca-se o domínio de estrangeiros de Cabo Verde, com 51,21\%, e de Guiné Bissau, com 25,95\%. Vale ressaltar que o gráfico trata do percentual de pessoas atendidas pela Polícia Federal, e que ela não tem controle sobre a dinâmica de tais pessoas dentro do País. Por exemplo, algumas apenas fazem escala em Fortaleza, podendo finalizar seu vôo em qualquer outro Estado da Federação. Todavia, os percentuais apresentados são relativos a vistos temporários, na condição de estudante.

\footnotetext{
${ }^{8} \mathrm{~A}$ escola não faz controle dos alunos matriculados de outras nacionalidades. 0 dado de 80 estudantes referente a 2016 foi devido a uma notificação da Polícia Federal, a fim de verificar a vinculação dos alunos com a escola. 


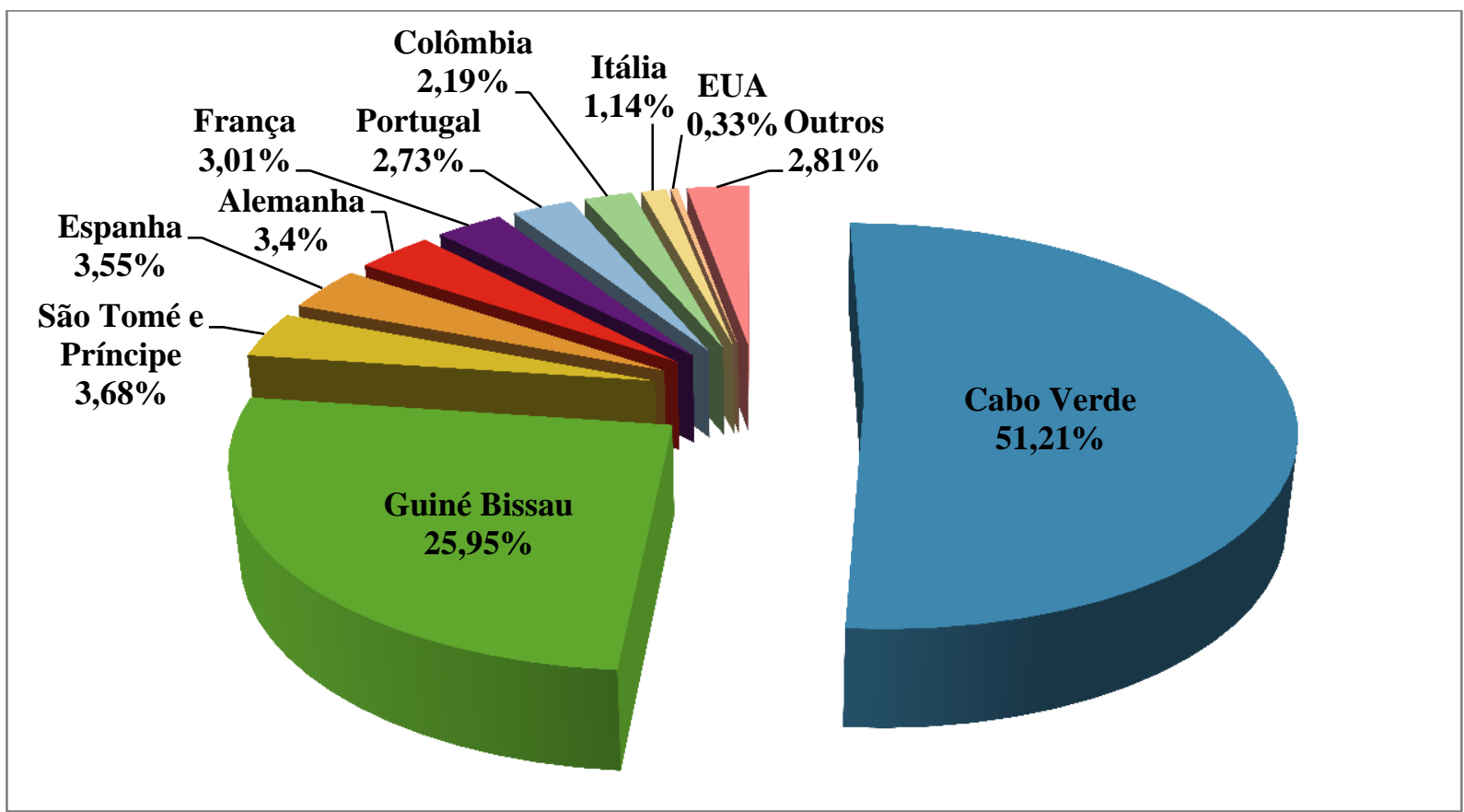

Gráfico 2: Percentual de atendimentos da Polícia Federal a estrangeiros no Aeroporto Internacional Pinto Martins (Fortaleza) entre janeiro de 2010 e março de 2017.

Fonte: Dados repassados pela Polícia Federal, por meio da Delegacia de Polícia de Imigração de Fortaleza.

Em nível nacional, a chegada de estrangeiros vem se tornando crescente. Apesar das dificuldades no provimento de serviços básicos (como educação, saúde e segurança pública), o controle feito pela Polícia Federal constata o crescimento, visto que, como já discutido, nosso País encontra-se em situação socio-econômica privilegiada frente aos demais países de língua portuguesa. O gráfico 3, que foi retirado do sítio da Polícia Federal, corrobora as discussões levantadas, quando deixa explícita a crescente demanda para um possível atendimento educacional para o estrangeiro. Vale relembrar que Tinavouta já havia relatado que Fortaleza representa uma capital com bom custo-benefício, principalmente em relação ao custo de vida, que na sua visão é relativamente menor que as demais grandes cidades brasileiras. 


\section{Estrangeiros (Quantidade por mil)}

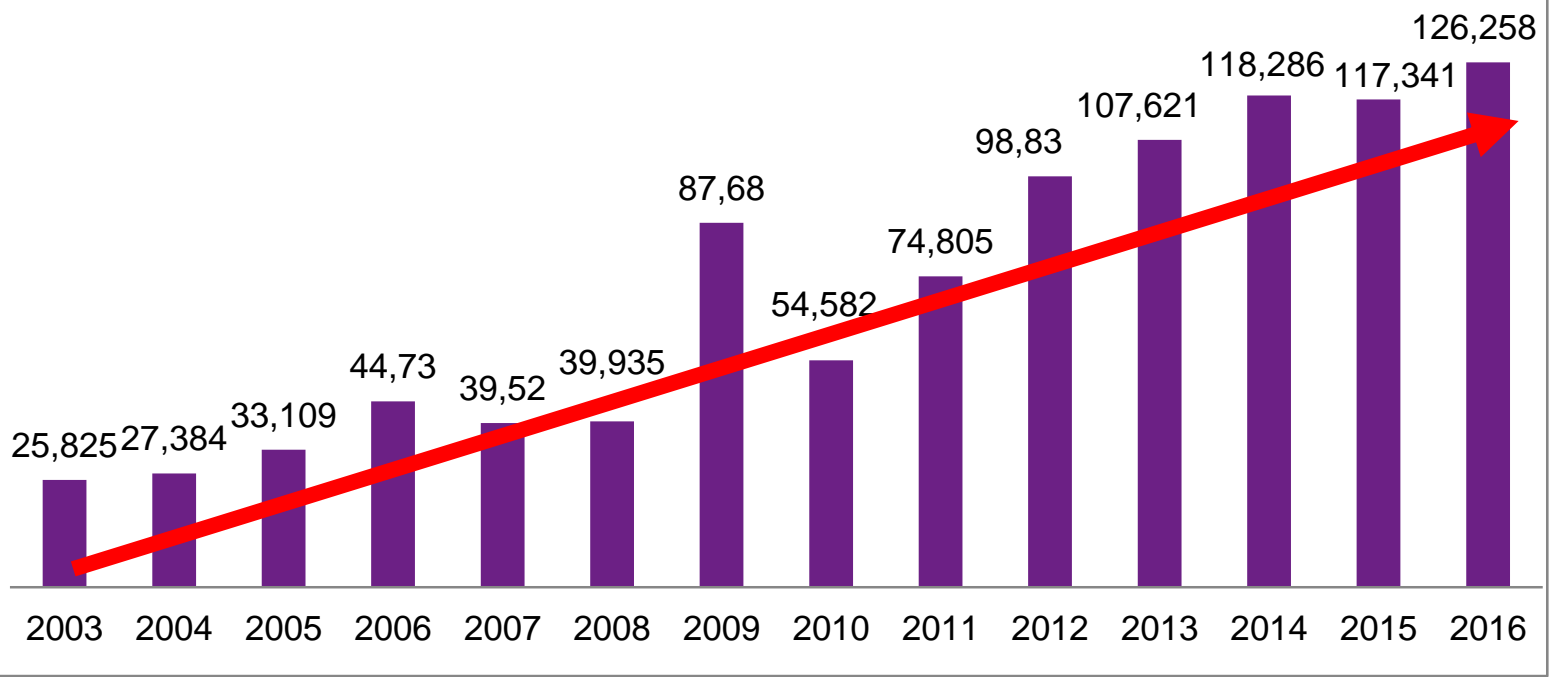

Gráfico 3: Evolução do número de estrangeiros no Brasil.

Fonte: Produzido a partir do gráfico do sítio da Polícia Federal: http://www.pf.gov.br/imprensa/estatistica/estrangeiros

O gráfico 3, que foi produzido a partir do sítio da Polícia Federal, exemplifica o que Magnólia pontuou anteriormente sobre o crescente aumento do número de estrangeiros. Apesar de os dados se referirem aos estrangeiros de todas as nacionalidades, é um parâmetro que pode reforçar a fala da secretária. Outro fator ponderável é o fato de o nosso país ter recebido grandes eventos nos últimos anos, tais como a Copa do Mundo de 2014 e as Olimpíadas ocorridas no Rio de Janeiro em 2016.

De acordo com os dados mais recentes da Polícia Federal, à época de 2015, segundo divulgou o Jornal Tribunal do Ceará, em 02 de setembro de 2015, 2.167 africanos possuem registro de residência no Ceará, vindos de diversos países africanos: Angola, Cabo Verde, Congo, Gana, Moçambique, Nigéria, Senegal, Serra Leoa, São Tomé e Príncipe e GuinéBissau - sendo que 1.116 dos residentes africanos no Ceará são guineenses. Os números evidenciam como é significativo o contingente de africanos em solo cearense, seja para obter maior qualificação profissional, seja por outros motivos pessoais. 


\section{Estrangeiros (Quantidades por mil)}

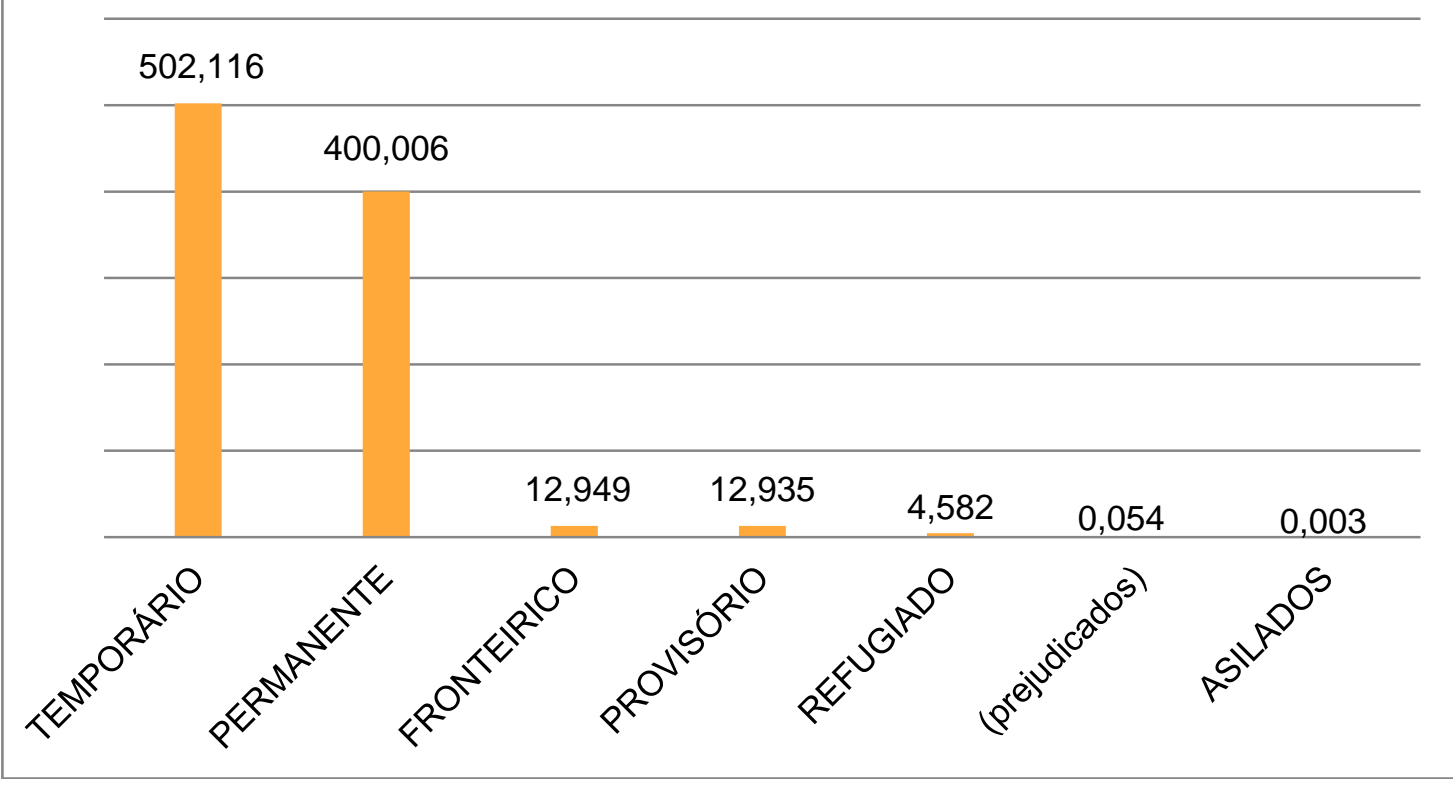

Gráfico 4: Modalidades de permanência de estrangeiros no Brasil ${ }^{9}$. Ano de referência: 2016. Fonte: Baseado no gráfico que está disponível em: http://www.pf.gov.br/imprensa/estatistica/estrangeiros

No gráfico 4, o número de estrangeiros temporários é consideravelmente maior. É importante deixar claro que os números são globais, envolvendo pessoas de diferentes nacionalidades. Todavia, para os gráficos 3 e 4, é evidente o número mais proeminente de estrangeiro nos últimos anos e em caráter temporário, mesmo com a crise financeira pela qual o Brasil passa desde 2015.

\footnotetext{
${ }^{9}$ VISTO TEMPORÁRIO: residentes provisórios, como estudantes, trabalhadores das mais diversas modalidades (profissionais), religiosos, imprensa, desportistas etc.

VISTO PERMANENTE: concedido ao estrangeiro que deseja se fixar definitivamente no território brasileiro, devendo, entretanto, atender as exigências previstas na seleção de imigrantes, que são estabelecidas pelo Conselho Nacional de Imigração.

VISTO FRONTEIRIÇO: ESTRANGEIRO que reside em país limítrofe em relação ao Brasil, e é domiciliado em cidade contígua ao território nacional, podendo exercer atividade remunerada no Brasil, sem possuir carteira de trabalho, desde que possua autorização da Polícia Federal. A Lei 6.815, de 19/8/1980, estabelece a admissão para atividade remunerada somente para os estrangeiros que possuírem visto temporário ou permanente ou fronteiriço.

VISTO PROVISÓRIO: concedidos para exercícios de atividades de curtos prazos.

VISTO PARA REFUGIADO: concedido àquele que comprova situações no seu país de origem de perseguição por razões de raça, religião, nacionalidade, grupo social ou opiniões políticas imputadas, ou ainda devido a uma situação de grave e generalizada violação de direitos humanos.

VISTO PARA PREJUDICADOS: estrangeiros em situação peculiar em relação demais tipos de vistos.

VISTO PARA ASILADOS: concedidos àqueles em situações políticas/diplomáticas, conforme Lei 6.815, de 19/8/1980.
} 
Quando questionei sobre sua percepção acerca do comportamento dos estudantes africanos no ambiente escolar, Magnólia informou que tais estudantes se destacam visualmente, pois sempre se vestem e usam cortes de cabelo típicos de seus países de origem. Vale salientar que, segundo Magnólia, os africanos usam o crioulo para conversar entre si, o que ajuda na sua identificação. A secretária percebe um distanciamento, que ocorre também por parte deles. Muitos são ríspidos quando se pronunciam na secretaria, postura que Magnólia entende como uma forma de "proteção".

Devido a esse comportamento rígido, e também porque alguns deles não falam o português brasileiro claramente, muitos funcionários buscam distanciamento, ficando a cargo dela e de outro funcionário (este da coordenação pedagógica) a missão de resolver eventuais imbróglios.

A respeito do parágrafo anterior, faço aqui uma intervenção. Em determinado momento, tentei entrevistar outros afrodescendentes, porém, devido a respostas hostis, preferi desistir. Uma estudante, que inclusive é estagiária na escola, sequer parou quando disse que gostaria de entrevistála. Os semblantes pareciam retratar um mesmo medo: o de ter que voltar ao país de origem. Apesar dessa percepção, o silêncio desses estrangeiros revela muito mais do que as falas de Tinavouta, por exemplo, e fatos alheios à minha sensibilidade de entrevistador podem estar transitar de forma despercebida.

Magnólia finalizou salientando que, apesar das dificuldades, a escola vem dando passos largos para melhoria em relação ao atendimento a essas pessoas, desde a parte burocrática, até o convívio em sala de aula. Apesar disso, não soube precisar a existência de acompanhamento pedagógico multidisciplinar.

Certo dia, um coordenador me solicitou atenção especial para com determinado estudante guineense, pois já havia ocorrido de um deles precisar refazer a prova de uma mesma disciplina diversas vezes, provavelmente pelo não entendimento do português brasileiro, ou ainda por falta de alfabetização. Cabe salientar que o fato acima descrito foi pontual, resultado da procura insistente do estudante por um tratamento mais adequado à sua necessidade. 
Apesar da fala de Magnólia, que defende que a escola vem buscando aproximação e integração com estudantes africanos, sou testemunha de que, pelo menos desde 2012, ano em que passei a compor o quadro de docentes da instituição, nunca presenciei um momento ou evento pedagógico que contemplassem alunos estrangeiros, evidenciando suas riquezas culturais e o quanto podem contribuir com a maturação dos processos de aprendizagem.

\subsection{A ORGANIZAÇÃO DAS DISCIPLINAS CURRICULARES}

Para evidenciar a presença ou possibilidade de integração de conteúdos ou eventos pedagógicos que considerassem a presença de alunos estrangeiros na escola, realizamos também análise da organização das disciplinas curriculares do curso em que o aluno, sujeito da pesquisa, estuda.

\begin{tabular}{|c|c|c|c|c|}
\hline \multirow{2}{*}{\multicolumn{2}{|c|}{ DISCIPLINAS }} & \multicolumn{3}{|c|}{ Carga Horária } \\
\hline & & \multirow{2}{*}{$\frac{\mathbf{T}^{*}}{45}$} & \multirow{2}{*}{$\begin{array}{c}\mathbf{P}^{\star \star} \\
5\end{array}$} & \multirow{2}{*}{$\begin{array}{c}\text { Total } \\
50\end{array}$} \\
\hline 1 & Materiais & & & \\
\hline 2 & Legislação e Ética Profissional & 25 & 0 & 25 \\
\hline 3 & Inglês Instrumental & 25 & 0 & 25 \\
\hline 4 & Eletricidade e Eletromagnetismo & 60 & 15 & 75 \\
\hline 5 & Eletrônica I & 60 & 15 & 75 \\
\hline 6 & Informática Aplicada & 15 & 35 & 50 \\
\hline 7 & Desenho Técnico & 25 & 50 & 75 \\
\hline 8 & Higiene e Segurança no Trabalho & 20 & 5 & 25 \\
\hline 9 & Metrologia & 10 & 15 & 25 \\
\hline 10 & Automação I & 20 & 30 & 50 \\
\hline 11 & Tecnologia Mecânica I & 45 & 30 & 75 \\
\hline 12 & Seleção e Resistência dos Materiais & 50 & 0 & 50 \\
\hline \multicolumn{2}{|r|}{ Módulo I - Introdutório } & 400 & 200 & 600 \\
\hline 13 & Lógica de Programação & 20 & 30 & 50 \\
\hline 14 & Eletrônica II & 30 & 20 & 50 \\
\hline 15 & Tecnologia Mecânica II & 70 & 30 & 100 \\
\hline 16 & Intalações Elétricas I & 60 & 40 & 100 \\
\hline 17 & Elementos de Máquinas e Lubrificação & 65 & 10 & 75 \\
\hline 18 & Automação II & 20 & 30 & 50 \\
\hline 19 & Gestão Aplicada I & 25 & 0 & 25 \\
\hline 20 & Gestão Aplicada II & 25 & 0 & 25 \\
\hline 21 & Manutenção de Máquinas e Equipamentos & 75 & 50 & 125 \\
\hline \multicolumn{2}{|r|}{ Módulo II - Específico em Mecatrônica I } & 390 & 210 & 600 \\
\hline
\end{tabular}




\begin{tabular}{|c|c|c|c|c|}
\hline 22 & Instalações Elétricas II & 45 & 30 & 75 \\
\hline 23 & Máquinas Elétricas & 45 & 30 & 75 \\
\hline 24 & Eletrônica III & 45 & 30 & 75 \\
\hline 25 & Automação III & 35 & 15 & 50 \\
\hline 26 & Eletrônica IV & 40 & 35 & 75 \\
\hline 27 & Instalações Elétricas III & 20 & 5 & 25 \\
\hline 28 & Automação IV & 30 & 20 & 50 \\
\hline 29 & Robótica & 50 & 25 & 75 \\
\hline 30 & Automação V & 40 & 60 & 100 \\
\hline \multicolumn{2}{|c|}{ Módulo III - Específico em Mecatrônica II } & 350 & 250 & 600 \\
\hline 31 & Estágio Supervisionado & 0 & 400 & 400 \\
\hline & CARGA HORÁRIA TOTAL & 1140 & 1060 & 2200 \\
\hline
\end{tabular}

Tabela 2: Matriz curricular do curso técnico em mecatrônica.

Fonte: Dados disponibilizados pela secretaria da escola.

Notas:

*Carga horária teórica.

* Carga horária de prática em laboratório.

No curso de Técnico em Mecatrônica ${ }^{10}$, é evidente na matriz curricular (ver tabela 2) a ausência de disciplinas de integração, ou que remetam minimamente à pluralidade cultural no contexto do mercado de trabalho.

$\mathrm{Na}$ tabela 2, que foi cedida pela secretaria da escola, verifica-se a organização do curso em 31 disciplinas, divididas em três módulos, conferindo dezoito meses ininterruptos de estudo entre aulas teóricas, práticas e estágio supervisionado, com objetivos direcionados ao desenvolvimento de habilidades específicas do técnico em mecatrônica. Assim sendo, pode -se dizer que a matriz curricular, a exemplo dos demais cursos, assume características técnicas e está exclusivamente voltada ao mercado de trabalho.

Ainda sobre a matriz curricular, a disciplina Legislação e Ética Profissional talvez fosse aquela que suscitasse mais proximidade com 0 desenvolvimento das relações multiculturais. Todavia, em consulta à ementa, verifica-se que a disciplina tem como objetivo a formação jurídica, no que concerne ao pleno exercício da profissão de técnico. Com carga horária de

\footnotetext{
${ }^{10}$ Curso técnico subsequente, isto é, voltado ao público que já concluiu o ensino médio. É regulamentado pela Resolução № 06 do Conselho Nacional de Educação, da Câmara de Educação Básica, de 20 de setembro de 2012 (CNE/CEB Nº 6/2012).
} 
apenas 25 horas, com programa da disciplina prevê o estudo do sistema fiscalizador que compete à atividade de técnico, passando pela Lei do Técnico Industrial, pelo Decreto Federal 90.922/85 e pela resolução 1010/05, finalizando com o código de ética dos profissionais do Conselho Federal de Engenharia e Agronomia (CONFEA). Assim, não conseguimos encontrar nenhuma relação da ementa que pudesse conferir identidade ao estrangeiro africano, tornando-o mero expectador dos seus anseios.

O conteúdo da disciplina Legislação e Ética Profissional, em consonância com as demais ementas direcionam a formação do profissional para um pensamento hierárquico, sistemático e de otimização da produção de forma mecânica. Essas características remontam ao taylorismo/fordismo. Todavia, por oferecer cursos técnicos que trabalham constantemente alinhados com o desenvolvimento tecnológico cada vez mais ascendente.

\begin{abstract}
A mudança da base eletromecânica para a base microeletrônica, ou seja, dos procedimentos rígidos para os flexíveis, que atinge todos os setores da vida social e produtiva nas últimas décadas, passa a exigir 0 desenvolvimento de habilidades cognitivas e comportamentais, tais como análise, síntese, estabelecimento de relações, rapidez de respostas e criatividade em face de situações desconhecidas, comunicação clara e precisa, interpretação e uso de diferentes formas de linguagem, capacidade para trabalhar em grupo, gerenciar processos, eleger prioridades, criticar respostas, avaliar procedimentos, resistir a pressões, enfrentar mudanças permanentes, aliar raciocínio lógico-formal à intuição criadora, estudar continuamente, e assim por diante. (KUENZER, 2005, p. 9).
\end{abstract}

Um aspecto importante a se destacar diz respeito à fragmentação do trabalho pedagógico no ambiente escolar em que convivem diferentes áreas do conhecimento. Exemplo disso é a diferença de esforços no acompanhamento dos alunos. Alguns docentes são mais bem remunerados por lecionarem disciplinas específicas, que exigem maior qualificação. Outrossim, alguns professores fecham acordo para ministrarem cursos voltados para uma determinada área, e que normalmente têm valores de matrículas maiores do que a matrícula do curso técnico.

A disciplina de Desenho Técnico, por exemplo, normalmente é ministrada com o uso de um software específico para cada tipo de profissional. O programa de computador pode mudar de acordo com o projeto proposto para o técnico. A partir daí o estudante precisa fazer um curso à 
parte, isto é, voltado especificamente para sua formação. Atualmente, a escola pesquisada oferece 33 cursos específicos, dentre os quais, muitos deles já estão nas grades curriculares dos cursos técnicos, mas com uma carga horária reduzida.

A fragmentação pedagógica decorre justamente do desenvolvimento tecnológico e da relação entre as mais diferentes áreas do conhecimento.

Rodrigues e Leite (2015) fazem uma discussão do tema a respeito do tema multiculturalismo e o ensino de Física e Ciências. Afirmam que "a inserção do ensino de Física e Ciências em uma perspectiva multicultural requer um movimento geral que busca a construção de um espaço que contemple o outro de maneira mais igualitária e que questione 0 etnocentrismo de muitas práticas arraigadas" (p. 8).

A tabela 3, extraída do trabalho das pesquisadoras supracitadas, mostra um levantamento bibliográfico a respeito do tema que estamos discutindo, considerando revistas de ensino de Física e Ciências para o período de 2002 a 2012. Dos 12 periódicos classificados na tabela, o tema multiculturalismo é pouquíssimo discutido; associando o multiculturalismo ao ensino de Ciências, o número de artigos é praticamente inexistente, dando um pouco da dimensão e um alerta para que o tema passe a adquirir seu espaço no meio científico.

\begin{tabular}{|l|c|c|c|}
\hline \multicolumn{1}{|c|}{ Periódicos } & $\begin{array}{c}\text { Total de } \\
\text { artigos } \\
\text { consultados }\end{array}$ & $\begin{array}{c}\text { Artigos sobre } \\
\text { multiculturalismo }\end{array}$ & $\begin{array}{c}\text { Artigos sobre } \\
\text { multiculturalismo e ensino } \\
\text { de Ciências }\end{array}$ \\
\hline Cadernos de Pesquisa & 576 & 9 & 0 \\
\hline Ciência e Educação & 502 & 1 & 1 \\
\hline Educação em Revista & 342 & 3 & 2 \\
\hline Educação e Pesquisa & 505 & 4 & 2 \\
\hline Educação e Sociedade & 900 & 10 & 2 \\
\hline Educar em Revista & 476 & 4 & 0 \\
\hline História, Ciência, Saúde & 1218 & 0 & 0 \\
\hline Manguinhos & 284 & 4 & 0 \\
\hline Pro-Posições (Impressa) & 322 & 0 & 0 \\
\hline Pro-Posições (Online) & 607 & 0 & 0 \\
\hline $\begin{array}{l}\text { Revista Brasileira de } \\
\text { Ciências Sociais }\end{array}$ & 599 & 11 & $\begin{array}{l}\text { Revista Brasileira de } \\
\text { Educação }\end{array}$ \\
\hline
\end{tabular}




\begin{tabular}{|l|c|c|c|}
\hline $\begin{array}{l}\text { Revista do Instituto de } \\
\text { Estudos Brasileiros }\end{array}$ & 176 & 0 & 0 \\
\hline TOTAL GERAL & 6.507 & 46 & 8 \\
\hline
\end{tabular}

Tabela 3: Levantamento bibliográfico para o período de 2002 a 2012.

Fonte: Extraído de (RODRIGUES; LEITE, 2015).

Gimeno Sacristán (2000) afirma que o debate sobre o que exatamente deve ser ensinado foi direcionado com base na tradição anglo-saxã e no currículo, sendo considerados os conteúdos e suas finalidades, para somente depois ampliar seu conceito. Ressalta ainda a existência de uma corrente dominante na história do desenvolvimento científico, que dividiu os conteúdos do ensino sobre o currículo da instrução.

Luckesi (1987) traz à tona a dificuldade de se trabalhar a interdisciplinaridade. Em tempos modernos, não se pode admitir que os conteúdos sejam "repassados" em formas bem definidas, sem margem para contribuição dos alunos, desconstruindo-se, assim, o processo de ensinoaprendizagem de fato. Luckesi (1987, p. 1) ainda acrescenta que "em nossas múltiplas relações, estamos dialeticamente situados num contexto educacional. Todos somos educadores e educandos, ao mesmo tempo".

Dessa forma, a integração curricular e humana torna-se cada vez mais uma necessidade. Para tanto, os aspectos educacionais devem assumir um papel de transversalidade no currículo dos cursos técnicos e profissionalizantes, isto é, condições pedagógicas permanentes precisam perpassar por toda a estrutura curricular. Isso deve contribuir para um ambiente saudável e que prima pelo sentimento de cooperação mútua, que se inicia no recinto escolar, até alcançar os mais diversos ambientes de trabalho.

\section{CONSIDERAÇÕES FINAIS}

O estudo em questão levantou uma importante discussão sobre currículo e multiculturalismo, tendo como ponto de reflexão os estudantes africanos que moram na cidade de Fortaleza e que frequentam escolas técnicas profissionalizantes, visto que é cada vez maior a procura por essas escolas. 
Tomando-se por referência a realidade apresentada pela polícia federal e a escola pesquisada e o estudo de caso feito com um aluno africano, o trabalho revelou alguns motivos pelos quais os africanos optam por morar em Fortaleza. Segundo Tinavouta, Fortaleza é uma cidade de boas oportunidades e de relativo baixo custo de vida, apesar de ainda ser vista como bastante violenta.

O estudo de caso mostrou ainda que o estudante africano relata ainda sofre com a rejeição e o distanciamento por parte de algumas pessoas, mesmo depois de 129 anos de abolição da escravatura. O fantasma do sentimento de inferioridade parece ainda muito presente, e a pesquisa possibilitou profundidade e clareza na tratativa dos diversos aspectos que envolvem o ser humano, dentre eles o social, o econômico e o político, pelos quais cruzamos ao longo do artigo.

Apesar da dificuldade de encontrar voluntários para a pesquisa, é importante uma discussão mais abrangente, envolvendo outros estudantes, de nacionalidades diferentes, a fim de que se chegue a uma conclusão mais efetiva em relação a esse público.

O artigo suscitou ainda acerca da necessidade dos profissionais de educação em buscarem capacitação para o bom relacionamento no ambiente de aprendizagem. A harmonia entre as diferentes áreas do conhecimento deve passar pela convicção e ciência do ser humano como protagonista de seu papel na construção do bem comum coletivo.

Por fim, constatamos a necessidade de integração do currículo dos cursos profissionalizantes em relações de aprendizagem que permitam 0 compartilhamento mútuo de ideias e conhecimentos que promovam um convívio social mais saudável e humano. Sem isso, a individualidade assume posição de destaque frente aos desafios de busca por ambientes de formação e de trabalho cada vez mais saudáveis.

\section{REFERÊNCIAS}

GOMES, Marianna. Africanos quebram barreiras, mudam cenário e já somam mais de 2 mil no Ceará. Disponível em: 
<http://tribunadoceara.uol.com.br/noticias/cotidiano-2/africanos-quebrambarreiras-e-ja-somam-mais-2-mil-no-ceara>. Acesso em: 30 mai. 2017.

BOURDIEU, Pierre. Lesstructuressociales de l'économie. Paris: Seuil, 2000. In: COELHO, W. N. B. A cor ausente: um estudo sobre a presença do negro na formação de professores. 2005. $253 \mathrm{f}$. Tese (Doutorado) Programa de Pós-Graduação em Educação, Universidade Federal do Rio Grande do Norte, Natal, 2005. Disponível em:

<http://repositorio.ufrn.br:8080/jspui/bitstream/123456789/14118/1/WilmaNBC .pdf>. Acesso em: 25 jan. 2017.

BARROSO, Marta. América Latina é novo destino de refugiados

africanos. Disponível em: <http://www.dw.com/pt-br/am\%C3\%A9rica-latina$\%$ C3\%A9-novo-destino-de-refugiados-africanos/a-4921257>. Acesso em: 06 jul. 2017.

BHABHA, H. K. O local da cultura. Trad: Myriam Ávila, Eliana Lourenço de Lima Reis, Gláucia Renate Gonçalves. Belo Horizonte: Editora da UFMG, 1998.

BRASIL. Lei no $\mathbf{1 0 . 6 3 9}$ de janeiro de 2003. Altera a Lei no 9.394, de 20 de dezembro de 1996, que estabelece as diretrizes e bases da educação nacional, para incluir no currículo oficial da Rede de Ensino a obrigatoriedade da temática "História e Cultura Afro-Brasileira", e dá outras providências, Brasília, DF, 2003. Disponível em:

<http://www.planalto.gov.br/ccivil_03/leis/L9394.htm> Acesso em: 06 jan. 2017.

BRASIL. Ministério da Educação: Conselho Nacional de Educação.

Resolução no 6, de 20 de setembro de 2012. Disponível em:

<http://portal.mec.gov.br/index.php?option=com_docman\&view=download\&ali as $=11663$-rceb006-12-pdf\&category_slug=setembro-2012-

pdf\&ltemid=30192>. Acesso em 06 jul. 2017.

BRASIL. Ministério da Justiça e Cidadania: Polícia Federal. Disponível em:<http://www.pf.gov.br/imprensa/estatistica/estrangeiros>. Acesso em 25 jan. 2017.

CANEN, A. Multiculturalismo e formação docente: experiências narradas. Educação e Realidade, v. 24, № 2, p. 89-102, 1999.

. O multiculturalismo e seus dilemas: implicações na educação.

Revista comunicação e política, v.25, n.2, p.091-107, 2007. Disponível em: <http://www.cebela.org.br/imagens/Materia/02DED04\%20Ana\%20Caren.pdf>. Acesso em: 03 jul. 2017.

GRANT, N. Intercultural perspective and knowledge for equity in the Mercosul countries: limits and potentials in educational policies.

Comparative Education, v. 35, no 3, p. 319-330, 1999. 
MOREIRA, A. F. B. Reflexões sobre o multiculturalismo na

escola e na formação docente. In: (orgs.). Ênfases e omissões no currículo. São Paulo: Papirus. p. 15-43, 2001.

CEARÁ É DESTINO ACADÊMICO PARA ESTUDANTES AFRICANOS. Disponível em:

<http://diariodonordeste.verdesmares.com.br/cadernos/cidade/ceara-edestino-academico-para-estudantes-africanos-1.691145>. Acesso em: 06 de jan.2017.

COELHO, W. N. B. A cor ausente: um estudo sobre a presença do negro na formação de professores. 2005. 253 f. Tese (Doutorado) - Programa de PósGraduação em Educação, Universidade Federal do Rio Grande do Norte, Natal, 2005. Disponível em:

<http://repositorio.ufrn.br:8080/jspui/bitstream/123456789/14118/1/WilmaNBC .pdf>. Acesso em: 25 jan. 2017.

; COELHO, M.C. Os conteúdos étnico-raciais na educação brasileira: práticas em curso. Educar em Revista, Curitiba, Brasil, n. 47, p. 67-84, jan./mar. 2013. Editora UFPR. Disponível em: <http://www.scielo.br/pdf/er/n47/06.pdf>. Acesso em: 25 jan. 2017.

FALCÃO, Carla. Brasil cresce 2,7\% em 2011 e vira 6⿳a economia do mundo, 2012. Disponível em: <http://economia.ig.com.br/economiabrasileira-cresce-27-em-2011/n1597665838398.html>. Acesso em 29 de abr. 2017.

FREIRE, Paulo. Pedagogia do Oprimido, $17^{\mathrm{a}}$ ed. Rio de Janeiro: Editora Paz e Terra, 1987.

GARCIA, Daniela. UOL. Em vídeo, recrutadores têm reações diferentes diante de negros e brancos. Disponível em: <https://noticias.uol.com.br/cotidiano/ultimas-noticias/2016/11/17/reacao-derecrutadores-muda-em-relacao-a-raca-de-pessoas-mostra-video.htm>. Acesso em: 10 jul. 2017.

GONÇALVES, Jonuel. Estudantes africanos miram o Brasil para estudos superiores. Disponível em: <http://br.rfi.fr/brasil/20160228-estudantesafricanos-miram-o-brasil-para-estudos-superiores>. Acesso em: 06 jul. 2017.

GONÇALVES. L. A. O.; SILVA, P. B. G. Multiculturalismo e educação: do protesto de ruas a propostas políticas. Revista Educação e Pesquisa, São Paulo, vol. 29, n. 1, p. 109-123, Jan./Jun., 2003. Disponível em: <http://www.scielo.br/pdf/ensaio/v16n60/v16n60a06.pdf>. Acesso em: 03 jul. 2017.

GOOGLE PUBLIC DATA EXPLORER. Disponível em: <https://www.google.com/publicdata/explorer>. Acesso em: 29 abr. 2017. 
GOVERNO DO PARANÁ. Secretaria da Juventude. O Racismo Institucional. Disponível em: < http://www.contraracismo.pr.gov.br/>. Acesso em: 10 jul. 2017.

KUENZER, A. Exclusão includente e inclusão excludente: a nova forma de dualidade estrutural que objetiva as novas relações entre educação e trabalho. In: SAVIANI, D.; SANFELICE, J.L.; LOMBARDI, J.C.(Org.). Capitalismo, trabalho e educação. 3. ed.Campinas: Autores Associados, 2005.

LUCKESI, Cipriano Carlos. 0 papel da didática na formação do educador. In: A Didática em Questão. Petrópolis: Vozes, 1987.

MANEL, A.; AMÂNCIO, T. Negros ocupam só $18 \%$ dos cargos de elite, aponta levantamento. Disponível em:

<http://www1.folha.uol.com.br/cotidiano/2015/06/1638879-negros-ocupam-so18-dos-cargos-de-elite-aponta-levantamento.shtml>. Acesso em: 10 jul. 2017.

ONU. Nações Unidas no Brasil. Grupo de Trabalho da ONU sobre Afrodescendentes divulga comunicado final sobre visita ao Brasil. Disponível em: <https://nacoesunidas.org/grupo-de-trabalho-da-onu-sobreafrodescendentes-divulga-comunicado-final/>. Acesso em: 10 jul. 2017.

PETIT, Sandra Haydée; ALVES, Maria Kellynia Farias; MACHADO, Adilbênia Freire. Memórias de Baobá II. Fortaleza: Imprece, 2015.

PETIT, Sandra Haydée. Pretagogia: Pertencimento, Corpo-Dança Afroancestral e Tradição Oral Africana na Formação de Professoras e Professores. Fortaleza: Editora UECE, 2015.

IMF. INTERNATIONAL MONETARY FUND. Transcript of the Press Conference on the Release of the October 2016 World Economic Outlook. Disponível em:

<http://www.imf.org/en/News/Articles/2016/10/04/AM16-TR100416-Transcriptof-October-2016-World-Economic-Outlook>. Acesso em: 29 abr. 2017.

ROCHEL, Luiz Cezar Elias. Desempenho Setorial. Associação Brasileira da Indústria Elétrica e Eletrônica (Abinee), São Paulo, Brasil. Disponível em: <http://www.abinee.org.br/abinee/decon/decon15.htm>. Acesso em: 29 abr. 2017.

GIMENO SACRISTÁN J. O currículo: os conteúdos do ensino ou uma análise prática. In: ; PÉREZ GÓMEZ, A. I. Compreender e transformar o ensino. 4. ed. Porto Alegre: ArtMed, 2000.

RODRIGUES, M. S., LEITE, C. Multiculturalismo e ensino de Física e Ciências: um levantamento bibliográfico em periódicos brasileiros. Revista de Enseñanza de la Física. Vol. 27, No. Extra, Nov. 2015, 219-227. Disponível em: 
<https://revistas.unc.edu.ar/index.php/revistaEF/article/viewFile/12606/12882> . Acesso em: 10 jul. 2017.

SANTOS, Akiko, SUANNO, João H. e SUANNO, Marilza V.R. (Orgs.). Didática e formação de professores: complexidade e transdisciplinaridade. Porto Alegre: Sulina, 2013.

SOUZA, Lynn Mario T. Menezes de. Hibridismo e tradução cultural em Bhabha. In: ABDALA JÚNIOR, Benjamin (org). Margens da cultura:

mestiçagem, hibridismo \& outras misturas. São Paulo: Boitempo Editorial, 2004. P. 113-133.

THE WORLD BANK GROUP. World Development Indicators. Disponível em: <http://databank. worldbank.org/data/reports.aspx?source=2\&country=BRA\#>. Acesso em: 29 abr. 2017.

UNILAB - INSTITUCIONAL. Disponível em:

<http://www.unilab.edu.br/institucional-2/>. Acesso em: 25 jan. 2017.

VIEIRA, Isabela. Grupo da ONU reconhece racismo como problema estrutural no Brasil. Disponível em:

<http://www.ebc.com.br/noticias/brasil/2013/12/grupo-da-onu-reconheceracismo-como-problema-estrutural-da-sociedade>. Acesso em: 10 jul. 2017.

WERNECK. V.R. Uma avaliação sobre a relação multiculturalismo e educação. Ensaio: aval. Pol. Publ. Educ.; Rio de Janeiro, v. 16, n. 60, p. 413-436, jul./set. 2008. Disponível em:

<http://www.scielo.br/pdf/ensaio/v16n60/v16n60a06.pdf>. Acesso em: 03 jul. 2017. 